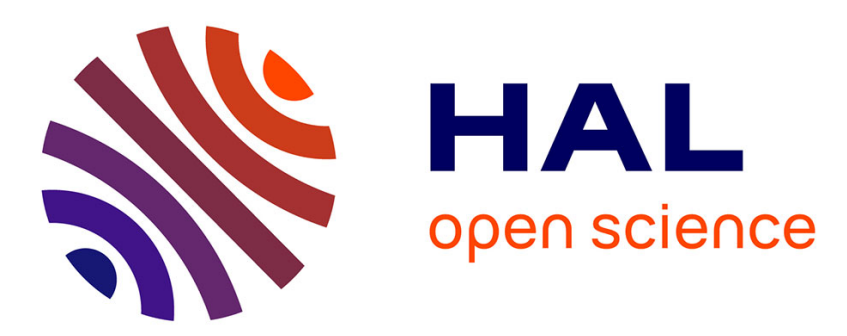

\title{
Annual and daily changes in plasma gonadotropin and sex steroids in relation to teleost gonad cycles
}

\author{
Yonathan Zohar, Roland Billard
}

\section{To cite this version:}

Yonathan Zohar, Roland Billard. Annual and daily changes in plasma gonadotropin and sex steroids in relation to teleost gonad cycles. Transactions of the American Fisheries Society, 1984, 113, pp.444-451. 10.1577/1548-8659(1984)1132.0.CO;2 . hal-02728608

\section{HAL Id: hal-02728608 \\ https://hal.inrae.fr/hal-02728608}

Submitted on 2 Jun 2020

HAL is a multi-disciplinary open access archive for the deposit and dissemination of scientific research documents, whether they are published or not. The documents may come from teaching and research institutions in France or abroad, or from public or private research centers.
L'archive ouverte pluridisciplinaire HAL, est destinée au dépôt et à la diffusion de documents scientifiques de niveau recherche, publiés ou non, émanant des établissements d'enseignement et de recherche français ou étrangers, des laboratoires publics ou privés.

\section{다(1)(2)}

Distributed under a Creative Commons Attribution - ShareAlikel 4.0 International 


\title{
Annual and Daily Changes in Plasma Gonadotropin and Sex Steroids in Relation to Teleost Gonad Cycles
}

\author{
Y. ZOHAR ${ }^{1}$ AND R. BILLARD \\ Institut National de la Recherche Agronomique, Laboratoire de Phisiologic des Poissons \\ Campus de Beaulieu, 35042 Rennes Cedex, France
}

\begin{abstract}
Long-term (annual and seasonal) variations in plasma concentration of reproductive hormones (maturational gonadotropin GTH and sex steroids) have been studied in relation to the gonad cycle in some teleosts. Plasma-GTH concentrations are low and increase only gradually during the major part of gonad development (vitellogenesis, spermatogenesis) but increase sharply towards the end of gametogenesis - that is, around the time of oocyte maturation and ovulation and before the start of spermiation. In females, plasma concentrations of $17 \beta$-estradiol and estrone rise continuously during vitellogenesis. ln salmonids, after a decrease in $17 \beta$-estradiol concentration starting at the end of the vitellogenesis, there is a small peak in testosterone

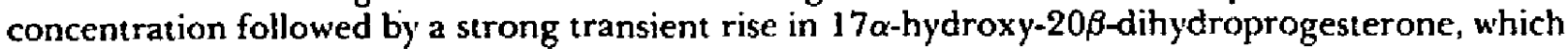

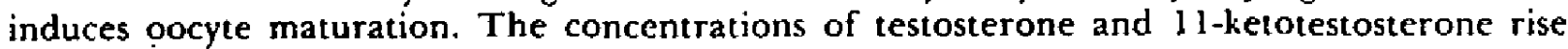
during spermatogenesis. Maximal concentrations of 11 -ketotestosterone were recorded in rainbow trout Salmo'gairdneri just prior to the start of spermiation. Plasma concentrations of both androgens in this species dropped during spermiation, whereas that of $17 \alpha$-hydroxy-20 $\beta$-dihydroprogesterone showed an important rise. Short-term (circadian and ultradian) variations in concentrations of reproductive hormones in teleosts have been less studied. Daily fluctuations in plasma GTH and in sex steroid concentrations, the pattern of which depends on the development stage of the gonads, have been demonstrated in a few fish species. Pulsed gonadotropin secretion occurs in some phases of gametogenesis in rainbow trout and common carp Cyprinus carpio.
\end{abstract}

The various external factors that impinge on fish are integrated at the level of the central nervous system. They interact with the hypothalmus-pituitary-gonad axis so that gametogenesis and spawning are, in part, put in phase with the environment via changes in hormone secretion.

\section{Long-Term Secretion Profiles}

Seasonal variations in plasma and pituitary gonadotropic hormone (G'TH) concentrations and in those of circulating steroids have becn studied intensively in fish over the last few years. This research mainly has concerned adult animats, and has been based on sampling at stated times (monthly and sometimes weekly). In some cases, these profiles have been studied in experiments that used daily photoperiods that varied through the year; most involved salmonids.

There are many data on these hormone profiles in trout and they seem to vary widely among

Present address: National Center for Mariculture, Israel Oceanographic and Limnological Research Institute, Post Office Box 1212, Fla1, Israt. fish strains (Scott and Sumpter 1983; Bromáge et al, in press), making it difficult to define a standard profile. In this review we discuss some profiles observed in rainbow and brown trout, Salmogairdneri and S. trutta. References to " $17 \alpha$ -

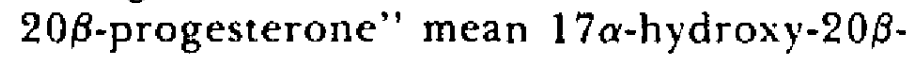
dihydroprogesterone; "estradiol" or " $\mathrm{E}_{\mathrm{a}}$ " mean $17 \beta$-estradiol.

The cycle of testicular development is well defined. Various cell types appear successively while test is size increases considerably (Fig. 1). At the beginning of spermatogenesis, circulating and pituitary GTH rises, temporarily, while plasma androgens remain low. During sperrmatogenesis, pituitary and plasma $\mathrm{G}^{-1} \mathrm{H}$ increase slightly. A rise in the androgen concentration occurs later, becoming maximal at the onset of spermiation when plasma GirH decreases (Fostier et al. 1982). Spermiation stops when androgen (mainly 11-ketotestosterone) values are minimal. There is also a possible role of $17 \alpha-20 \beta$-progesterone on spermiation in some strains of rainbow trout (Scot t and Baynes 1982).

In the female (Fig. 2), the annual cycle shows a short rise in plasma and pituitary gonadotro- 


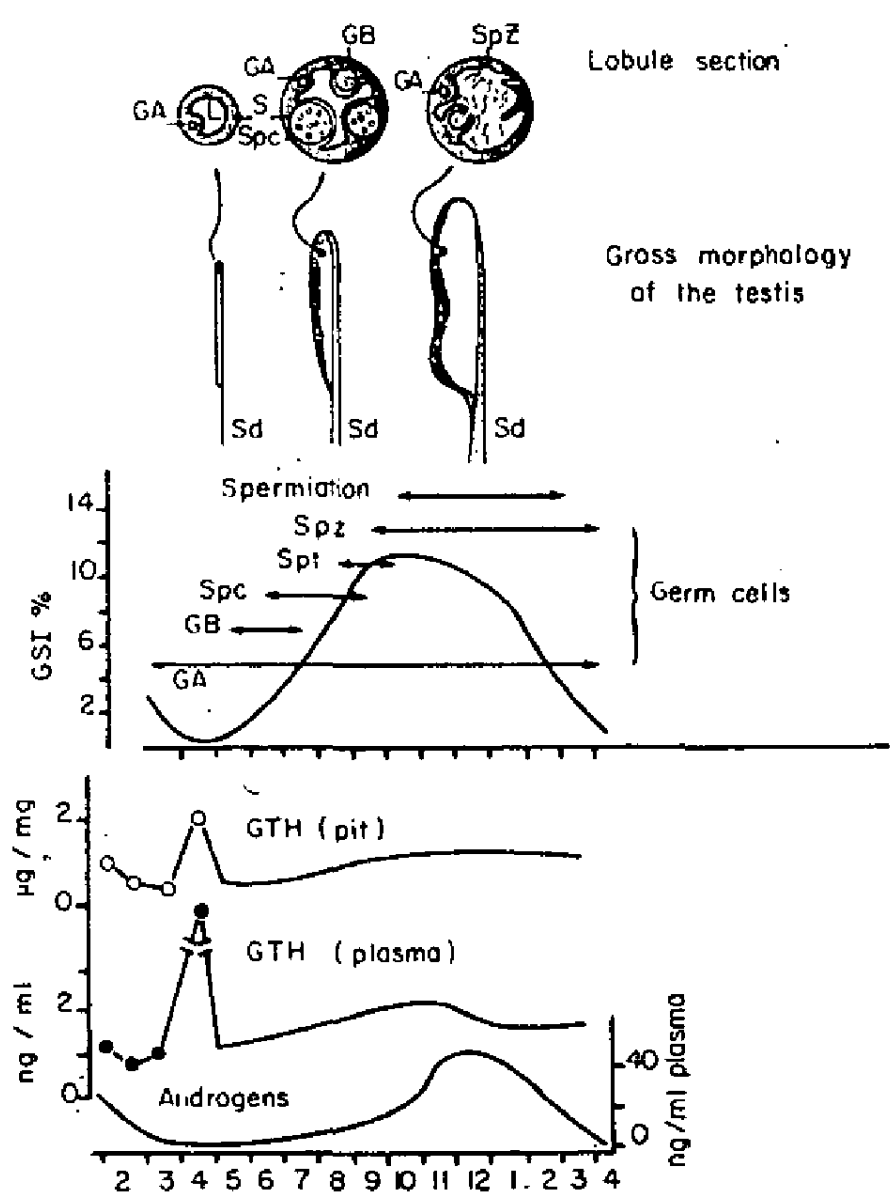

Figure 1:-Diagram of rainbou' troul spermatogeneticgcle. GA, GB: type A and B spermatogonia; Spc: spermatocyte; Spt: spern tatid; Spz: spermatozoon; Sd: sperm duct; GSI is gonadocomatic index (100 gonad ureight/ body weight); G7H (gonadotropin) in the pituitary (pit) is given in $\mathrm{\mu g}$ / mg fresh tissue. Abscissas are scaled in months.

pin (brown trout: Breton et al. 1983) at the onset-of ovarian recrudescence, while the estradiol concentration generally remains low and stable (Lambert et al. 1978; Whitehead, et al. 1978; Whitehead ${ }_{2}$ et al. 1978; Scott et al. 1980; Bohemen and Lambert 1981; Breton et al. 1983); although in some cases, it may increase slightly (Billard et al. 1978; Breton et al., in press). During vitellogenesis, plasma gonadotropin, estradiol $\mathrm{E}_{2}$, and testosterone gradually increase (Scott and Sumpter 1983; previous references). Most of these authors noted a decrease in $\mathrm{E}_{2}$ before and during oocyte maturation (Fostier et al. 1978; Bromage, et al. 1982; Bromage ${ }_{2}$ et al. 1982), whereas there is a temporary rise in testosterone before $17 \alpha-20 \beta$-progesterone increases (Fostier et al. 1981; Fostier and Jalabert 1982; Scott et al. 1982; Wright and Hunt 1982). The elevation of circulating GTH seen during oocyte maturation continues after ovulation (Jalabert and Breton 1980).
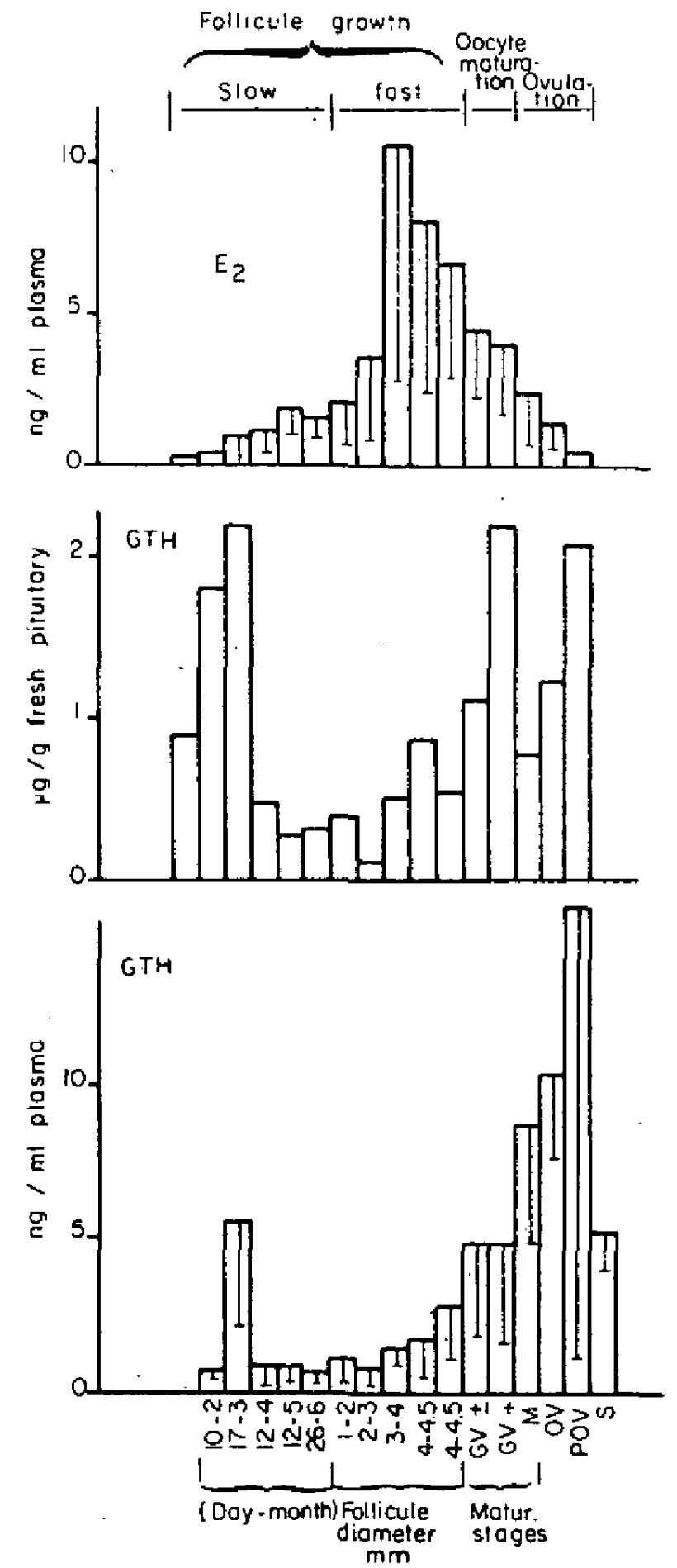

Ficurf. 2.-Estradiol $\left(E_{2}\right)$ and gonadotropin $(G T H)$ profiles during zilellogenesis, oocvte maturation, and or $u$. lation in brou'n trout (second reproductive cycle). $\mathrm{GV}$ : germinal i'psicle; M: maturation; OV: nitulation; POV: postotulation (egg in the body catily): S: spent. (From Billard et al. 1978; Breton et al. 1983.)

\section{Short-Term Secretion Profiles}

Compared to work on other hormone secretions or other circadian activity rhythms (for example, spawning, locomotion, feeding), very few detailed studies have been done on shortterm reproductive hormone profiles (gonadotropins or sex steroids) in fish.

In cyprinids, de Vlaming and Vodicnik (1977a, 


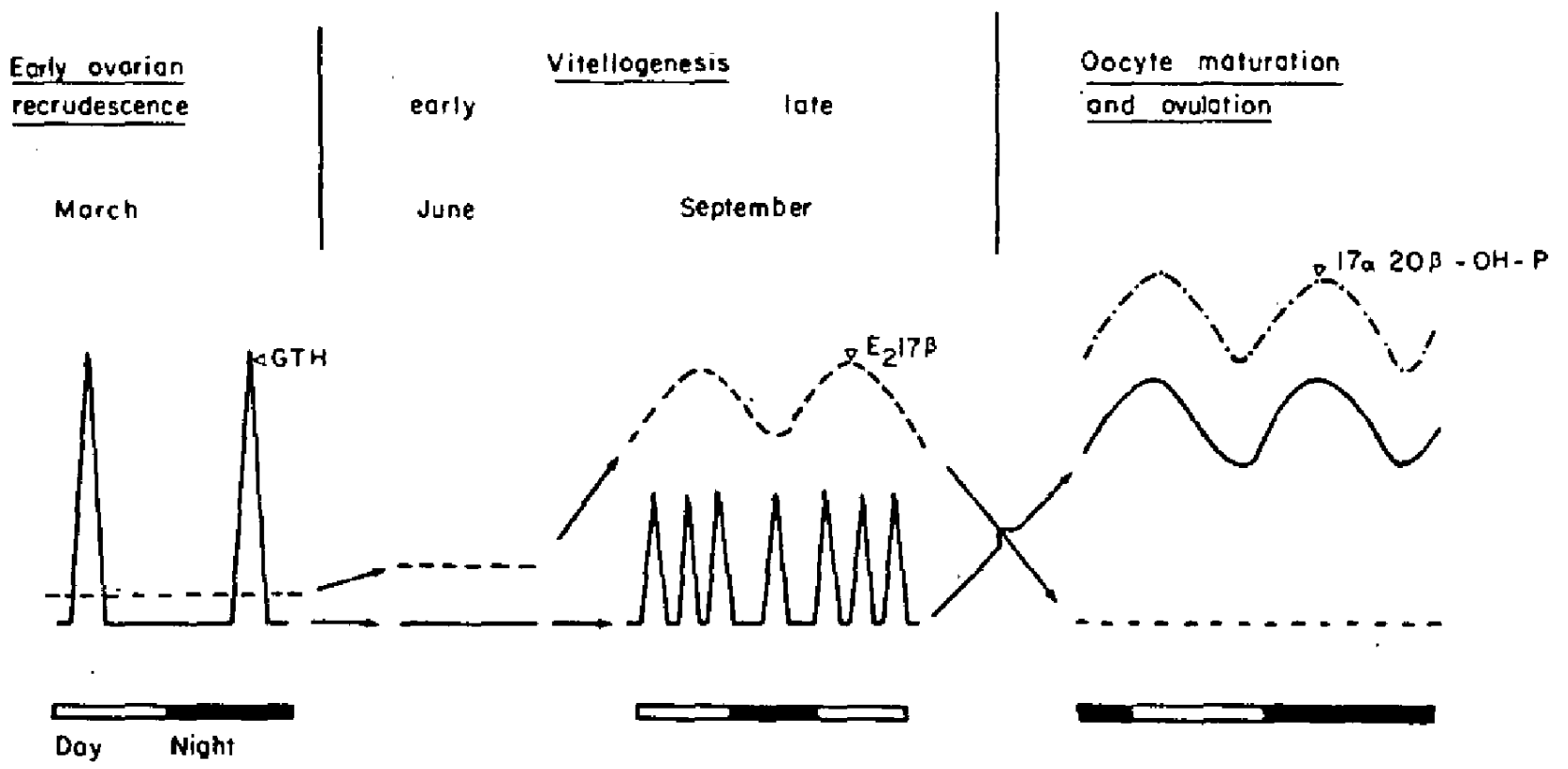

FiGURF 3.- Schematic presentation of the short-tern secretion patlern of gonadotropin $(G T H)$, estradiol $\left(E_{2} 17 \beta\right)$, and $17 \alpha-20 \beta$-progesterone $(O H-P)$ at different stages of the on'arian cycle in female rainbou' trout. (From Zohar 1982.)

$1977 b)$ showed daily changes in the concentration of GTH in the pituitary which are modified after pinealectomy. In goldfish Carassius auratus, diel variations in plasma GTH have been reported by several authors; these variations depend on such factors as temperature, photoperiod, dissolved-oxygen content, sex, and season. The first diel variations were demonstrated by Breton et al. (1972) in females during the preovulatory period and, to a lesser degree, in males. Stacey et al. (1979a) confirmed these observations on females and showed that release of ov'ulatory GTH occurred at a precise time during the diel cycle. Hontela and Peter (1978) showed that the daily fluctuations in plasma G'TH observed in female goldfish during spawning also were found in females with recrudescent ovaries but not in those at sexual rest (Hontela 1984, this issue). Daily fluctuations in plasma GTH concentrations also were noted in common carp Crprinus carpio and other carps (Jiaxiu et al. 1980). Sex steroids also may fluctuate during the diel cycle in common carp (K. Bieniarz 1982, personal communication), gulf killifish Fundulus grandis (MacGregor, in press), and the lndian cat fish Heteropmewstes fossilis (Lamba et al. 1983). However, Schreck et al. $(1972,1973)$ did not find any clear variation in circulating androgens and estrogens over a 24-hour period in male goldfish.

Among salmonids, Fostier et al. (cited by Billard and Breton 1978) observed slight changes in mean plasma GTH and testosterone values in male rainbow trout but without a clear-cut circadian cycle. Zohar (1982) demonstrated that fluctuations from the mean could not be clearly identified and that it was necessary to use serial sampling of the same animal. A catheterization technique was developed for this (Bry and Zohar 1980; Zohar 1980), which permitted detailed study of short-term changes in GTH and $E_{2}$ at different times of the reproductive cycle in female rainbow trout (Zohar 1982). During early ovarian recrudescence in March, there was no pulse in secretion of plasma $E_{2}$, but GTH showed erratic pulses of high amplitude (up to $100 \mathrm{ng} / \mathrm{ml}$ ) lasting $1-3$ hours and occurring once or twice at any time during a 24-hour period (Fig. 3). Later in June, when exogenous vitellogenesis started, there were no noticeable fluctuations in plasma $E_{2}$ and $G T H$. As the process of vitellogenesis progressed, pulses of GTH were recorded. They nere of low amplitude (less than $10 \mathrm{ng} / \mathrm{ml}$ ), lasted $1-3$ hours, and were more numerous during the day than during the night in October. At the same time, the $\mathbf{F}_{2}$ concentration rose and showed wide circadian variations overriding the GTH pulses. Just before and at the onset of oocyte maturation, GTH pulses were not observed: instead, there was a general rise in the basal concentration, which showed continuous diel fluctuations. Concentrations of $17 \alpha-20 \beta$-progesterone increased considerably and also showed wide circadian changes.

It thus appears that variations in the short- 
term secretion of gonadotropin and gonadal steroids in salmonids are superimposed on the long-term variations that had been recorded earlier.

\section{Pulses and Cycles of Hormone Secretion}

Data in the literature show that pulsed hormone secretion occurs in many animals. In the higher vertebrates, pulses have been observed in the secretion of hypothalamic and pituitary hormones as well as in that of steroids (sexual or not), digestive hormones, and monoamines. A single organ can produce very diverse hormones, usually secreted in a pulsed mode (for example, various sex steroids and oxytocin secreted by the gonad). Endocrine rhythms often have been described in fish. Pituitary hormones, growth hormone $(\mathrm{GH})$, and prolactin also are released in circadian pulses (Leatherland and McKeown 1973) and the pituitary cells concerned show cyclic activities (Carrillo et al. 1980). Free fatty acids are secreted as pulses in Tilapia sp. (Zanuy and Carrillo 1981), sometimes even in relation to indoleamines (Johnes et al. 1980) whose levels vary with the diel cycle (Gern et al. 1978). The same is true of catecholamines (Boehlke et al. 1967; Sauerbier and Meyer 1977; Le Bras 1979). Other hormones involved in intermediary metabolism, such as thyroid hormones (Plisetskaya et al. 1983), also show circadian secretion (Spieler and Noeske 1979). In some cases, target organs, such as gonads, show a diel cycle of responsiveness to the effector hormone, such as gonadotropin (Kuo and Watanabe 1978). These experiments, in addition to numerous others reported in this issue, show that the cyclicity of hormonal activity (secretion, reception, sensitivity) is widely observed and that it concerns many physiological functions. The physiological significance of this rhythmicity is interesting and important to understand.

The pulsatility of GTH secretion can be related to regulatory mechanisms at the pituitary or gonad. In mammals, secretion of luteinizing hormone (or gonadotropin) releasing hormone (LHRH) is pulsatile (Carmel et al. 1976). This pulsatility is essential to the induction of gonadotropin secretion, which itself is pulsatile.

Repeated injections of LHRH-A have proven effective to induce ovulation (Chan 1977) and spermiation (Billard et.al. 1983: Takashima et al., in press) in common carp, although nonresponse has been reported in northern pike
Esox lucius (Billard and Marcel 1980). Implants of LHRH or LHRH-A in different salmonids induced the following biological responses: GTH secretion; oocyte maturation and ovulation $\left(\mathrm{Crim}_{2}\right.$ et al. 1983); spermiation (Weil and Crim 1983); and even spermatogenesis and vitellogenesis (Crim, et al. 1983). In one case, circulating GTH rose but blood sampling $1.5,3,6$, and 11 hours after LHRH and LHRH-A injections showed no pulses (Van der Kraak et al. 1983). These data might indicate that, in the fish species studied up to now, pulsed hormone secretion is not needed to induce certain biological responses.

The significance of GTH pulsatility in female rainbow trout also might relate to the regulation of gonadal steroid secretion. This was tested by Zohar (1982) in vitro. Perfused ovarian fragments responded to a physiological pulse of GTH with steroid secretion that varied in duration and intensity with the stage of follicular development and the intensity of the pulse. Ovarian fragments undergoing exogenous vitellogenesis responded to repeated GTH pulses with constantly elevated or even increased rates of estradiol production. For rainbow trout in early and advanced vitellogenesis, the GTH pulse might be the basic hypophysial signal and changes in its frequency might determine shortand long-term changes in circulating estrodiol concentrations. The pulsatile mode of GTH secretion might be the most efficient, or the only possible, way to induce an appropriate physiological response in the ovary. In some mammals, the phenomenon of "down regulation" exerted by GTH on the gonad explains the obligatory pulsatile pattern of gonadotropin secretion (Baird 1979; Desjardins 1981). Such regulatory mechanisms have not yet been established for fish.

As mentioned, after vitellogenesis, but before the onset of oocyte maturation, basal GTH increases and its secretion pattern changes from pulsatile to circadian. Concomitantly, there is a continuous decline of plasma estradiol and a transient surge of testosterone that is followed by a strong increase of $17 \alpha-20 \beta$-progesterone, which induces oocyte maturation. In vitro studies showed that parallel to these in vivo changes are marked modifications in ovarian steroidogenic capacity and responsiveness to GTH (Zohar 1982; Zohar et al. 1982). In vitro exposure of follicles at the onset of maturation (peripheral germinal vesicle) to a constant high GTH 
concentration ( $30 \mathrm{ng} / \mathrm{ml}$ ) caused the following chain of events: (1) a short increase, followed by a continuous decrease, in estradiol secretion; (2) an important transient increase in testosterone production; and (3) a continuous increase in the secretion rate of $17 \alpha-20 \beta$-progesterone, followed by oocyte maturation. These data suggest that the increasing GTH concentrations in vivo act on follicles ready to mature (1) by stimulating the production of androgens whose aromatization to estradiol is depressed, probably due to the GTH rise, and (2) by modulating activities of enzymes implied in the production of $17 \alpha-20 \beta$-progesterone. The maintenance of high testosterone and low estradiol concentrations probably contributes 10 an adequate steroid environment for the synthesis of $17 \alpha-20 \beta$ progesterone and for oocyte maturation (Jalabert and Fostier 1984). Thus, modifications both in GTH secretion and in follicular responsiveness to GTH probably are responsible for the change in steroid balance leading to oocyte maturation.

Another problem is: at which stages of oogenesis do these pulses of high GTH concentrations act, given that the oogenetic cycle probably extends over 2 years (Billard, in press)? During the first year, primary growth (previtellogenesis) begins, perhaps as a continuation of oogonial recruitment and meiosis. During the second year of the cycle, previtellogenic follicles beginning vitellogenesis are recruited. The most intense GTH pulses (up to $100 \mathrm{ng} / \mathrm{ml}$ ) are observed at exactly this time in spring; Zohar (1982) considers that they may be involved in the recruitment of previtellogenic follicles. Billard (in press) noted that the first stages of meiosis and previtellogenesis increase in the preovulatory period in brown trout, suggesting the intervention of GTH or of various steroids early in the oogenetic cycle. The complex events occurring in the periovulatory period in trout may not only concern the end of the cycle but also its beginning.

\section{Physiological Cycles and \\ Environmental Variations}

Is there any relationship between the cyclicity of various physiological activities observed in anjmals over short and long terms, on the one hand, and annual and daily variations in the environment, on the other? The relationship sometimes is evident in the case of melatonin where circadian secretion depends directly on the photoperiod because light inhibits the enzymes synthesizing the melatonin. In some mammals such as sheep, melatonin, controlled by photoperiod, acts to regulate reproduction via the induction of endogenous rhythms (Lincoln et al. 1982). Other environmental factors, and the activity cycles themselves, also could be activators. The urine of male mice secreted at a precise time of the diel cycle advances female puberty (Drickamer 1982). The loss of estrous cyclicity in aged female rats, due to changes in catecholamine activity cycles, can be recovered again when the females are put with young males (Wise 1982).

We do not yet have enough data to propose exactly how environmental factors are related to reproductive functions in fish, but several factors are involved and they may initiate endogenous rhythms. For example, temperature fluctuations could play a role in the amplification of diel fluctuations in goldfish (Breton et al. 1972). The same temperature variations also affect the status of cortisol and prolactin during the diel cycle. Oxygen concentrations, and probably their variations, act on reproduction (Gillet et al. 1981). Oxygen concentration fluctuates daily in many biotopes, such as ponds, due to variations in temperature and photoperiod that affect photosynthesis by phytoplankton and macrophytes. The latter form substrates for eggs and they may play a part in the induction of ovulation (Stacey et al. 1979b). Diet is also a cyclic factor due to the succession of light and dark phases (which aid or not the capture of prey) and to the behavior of the prey themselves, which also show diel variations (Bowman and Bowman 1980).

\section{Conclusions}

In fish, as in most species, the reproductive function is very seasonal in temperate zonles and even in the intertropical zone. Because this is also true of other functions, a great many physiological variables show annual fluctuations; on these are superimposed short-term variations occurring within a 24-hour period. 'These physiological changes appear either in direce response to environmental changes or in response to the induction or synchronization of endogenous rhythms. Hormonal signals act as mediators; they are numerous and diverse, superimposed and successive, and they concern very different functions. These functions are not independent, and it is evident, for example, that 
gametogenesis is related to the nutritional function: female fish accumulate stores in the gonads that may reach $30 \%$ of body weight. There is also an interaction, for example, with the processes of migration and smoltification. In this context, it is probable that a hormonal signal is given to several effectors; for example, melatonin involved in neuroendocrine control of reproduction also acts in glucose and free-fatty. acid metabolisms. The form of the signal may be important; the changes in form and frequency observed during a reproductive cycle represent information intended for several different physiological stages of the same target tissue and also for different target tissues.

Successful interventions to control fish reproduction, such as hormonal supplementation to induce ovulation (hypophysation), depend largely on knowledge of secretory rhythms.

\section{References}

BAIRD, D. T. 1979. Gonadotropic control of ovarian steroid secretion. Pages 177-184 in A. Klopper et al., editors. Research on steroids. Academic Press, New York, New York, USA.

BILLARD, R. In press. Gametogenesis in the brown trout (Salmo trutta fario) bred in captivity: a quantitative study. Cell Tissue Research.

BILlARD, R., AND B. BRETON. 1978. Rhythms of reproduction in teleost fish. Pages 31-53 in J. E. Thorpe, editor. Rhythmic activity of fishes. Academic Press, London, England.

Billard, R., B. Breton, A. Fostier, B. Jalabert, AND A. WEIL. 1978. Endocrine control of the teleost reproductive cycle and its relation to external factors: salmonid and cyprinid models. Pages $37-48$ in J. P. Gaillard and H. H. Boer, editors. Comparative endocrinology. Elsevier/ North Holland, Amsterdam, Netherlands.

Billaard, R., J. P. Choisis, and P. Reinaud. 1983. Stimulation of spermiation in carp in response to LHRH and D-Ala ${ }^{6} \cdot \mathrm{LHRH}$ ethylamide. Aquaculture 35:173-176.

Billard, R., AND J. MARCEL. 1980. Stimulation of spermiation and induction of ovulation in pike (Esox lucius). Aquaculture 21:181-195.

BOE.HLKF, K. W., O. W. TIEMEIFR, AND B. E. EleFTheriou. 1967. Diurnal rhythm in plasma epinephrine and norepinephrine in the channel catfish (Ittalurus punctatus). General and Comparative Endocrinology 8:189-192.

Bohemen, C. van, ano J. G. D. Lambert. 1981. Estrogen synthesis in relation to estrone, estradiol, and vitellogenin plasma levels during the reproductive cycle of the female rainbow trout, salmo gairdmeri. General and Comparative Endocrinology 45:105-114.

Bowsan, R. E., ANo E. W. Bowman. 1980. Diurnal variation in the feeding intensity and catchability of silver hake (Herluccius bilinearis). Canadian Journal of Fisheries Aquatic Sciences 37:15651572 .

Breton, B., R. Billard, B. Jalabert, ano G. KanN, 1972. Dosage radioimmunologique des gonadotropines plasmatiques chez Carassius auralus au cours du nycthémère et pendant l'ovulation. General and Comparative Endocrinology 18:463468

Bhfron, B., A. Fostler, Y. Zohar, P. Y. Le Ball, AND R. Billard. 1983. Gonadotropine glycoprotéique maturante et oestradiol-17 $7 \beta$ pendant le cycle reproducteur chez la truite fario (Salmo trutta) femelle. General and Comparative Endocrinology 49:220-231.

BRETON, B., Y. ZOHAR, AND R. BILLARD. In press. Photoperiod and gonadotropin control of the reproductive cycle in the female rainbow trout. In B. Loft, editor. Proceedings of the 9th Interna. tional Symposium on Comparative Fndocrinology, Hong Kong.

Bromage, N. R., J. A. K. Elliot, and J. Springate. In press. The use of altered seasonal and constant photoperiods in the production of all-year supplies of eggs in the rainbow trout. Aquaculture.

Bromage, N. R., C. Whitehfad, and B. Breton. 1982. Relationships between serum levels of gonadotropin, oestradiol- $17 \beta$ and vitellogenin in the control of ovarian development in the rainbow trout. II. The effects of alterations in environmental photoperiod. General and Comparative Endocrinology 47:366-376.

Bromage, N. R., C. WHITEHEAD, J. A. K. ElLIOT, B. BRETON, AND A. J. MATTY. 1982. Investigations into the importance of day length on the photoperiodic control of reproduction in the female rainbow trout. Pages 233-236 in C. J. J. Richter and H. J. T. Goos, compilers. Reproductive physiology of fish. PUDOC, Wageningen, Netherlands.

Bry, C., AND Y. ZOHAR. 1980. Dorsal aorta catheterization in rainbow trout. II. Glucocorticoid

levels, hematological data and resumption of feeding during five days after surgery. Reproduction, Nutrition, Développement 20:18251834.

Carmél, P. W., S. Araki, and M, Ferin. 1976. Pituitary stalk portal blood collection in rhesus monkeys: evidence for pulsatile release of gonad. otropin releasing hormone (Gn-RH). Endocrinology 99:243-248.

Carrillo, M. A., S. Zanuy, J. Kuo, and W. WataNABE. 1980. Daily rhythms of liver CAMP, total liver lipids, prolactin-like hormone and growth hormone cell activities in Sarotherodon mossambicus acclimated to different photoperiod regimes. General and Comparative Endocrinology 41:325-333.

CHax, K. S. K. 1977. Effect of synthetic luteinizing hormone-releasing hormone (LH-RH) on ovarian development in Japanese medaka, Oryzias latipes. Canadian Journal of Zoology 55:155-160. 
CRIM, L. W., D. M. Evans, ANd B. H. VICKeRY 1983. Manipulation of the seasonal reproductive cycle of the landlocked Atlantic salmon (Salmo salar) by LHRH analogues administered at various stages of gonadal development. Canadian Journal of Fisheries and Aquatic Sciences 40:61-67.

Crim $_{2}$, L. W., A. M. SuJThrlin, D. M. EvaNs, and C. WeIL. 1983. Accelerated ovulation by pelleted LHRH analogue treatment of spring-spawning rainbow trout (Salmo gairdneri) held at low temperature. Aquaculture 35:299-307.

Desjardins, C. 1981. Endocrine signaling and male reproduction. Biology of Reproduction 24:121.

DE VlaminC, V. L., AND M. J. VodiCNIK. 1977a. Effects of pinealectomy on pituitary gonadotrophs, pituitary gonadotropin potency and hypothalamic gonadotropin releasing activity in Nolemigonus crysoleucas. Journal of Fish Biology 10:7386.

DE Vlaminc, V. L., aNd M. J. VOdiCNIK. $1977 \mathrm{~b}$. Diurnal variations in pituitary gonadotropin content and in gonadal response of exogenous gonadotropin and prolactin in Notemigonus cysoleu. cas. Journal of Fish Biology 10:37 1-383.

DrickAMER, L. C. 1982. Acceleration and delay of sexual maturation in female mice via chemosignals: circadian rhythm effects. Biology of Reproduction 27:596-601.

Fostier, A., R. BllLARd, B. Brfton, M. Legendre, and S. Marlot. 1982. Plasma 11-oxotestoster. one and gonadotropin during the beginning of spermiation in rainbow' trout (Salmo gairdneri $\mathrm{R}$.). General and Comparative Endocrinology 46:428434.

Fostier, A., B. Breton, B. Jalabert, and O. Marcuzzı, 1981. Evolution des niveaux plasmatiques de la gonadotropine glycoprotéique et de la $17 \alpha$ hydroxy-20 $\beta$-dihydroprogestérone au cours de la maturation et de l'ovulation chez la truite arc-enciel (Salmo gairdneri). Comptes Rendus Hebdomadaires des Séances de l'A cadémie des Sciences, Série D, Sciences Naturelles 293:817-820.

Fostifk, A., ANd B. JAl.ABret, 1982. Physiological basis of practical means to induce ovulation in fish.. Pages 164-173 in C. J. J. Richter and H.J. T. Goos, compilers. Reproductive physiology of fish. PUDOC, Wageningen, Netherlands.

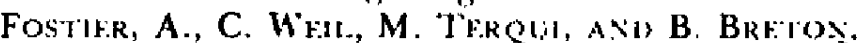
1978. Plasma estradiol- $17 \beta$ and gonadotropin during ov'ulation in rainbow troul Solmo gaird. neri. Annales de Biologie Animale. Biochimie, Biophysique 18:929-936.

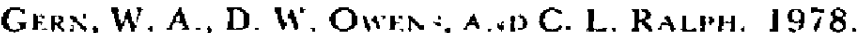
Plasma melatonine in rout: day-night changes detected by radioims.unoassay. General and Comparative Endocrinology 34:453-458.

Gill.ex, C., R. Billakd, ANi) B. BrfTox. 1981. La reproduction du poisson rouge Carassius auratus élevé à $30^{\circ} \mathrm{C}$ : effet de la photopériode, de l'alimentation et de l'oxygenation. Cahiers du Laboratoire de Montereau 1 1:49-56.
Hontela, A., and R. E. Pfiter, 1978. Daily cycles in serum gonadotropin levels in the goldfish: effects of photoperiod, temperature and sexual condition. Canadian Journal of Zoology 56:24302442.

JALABF.RT, B., AND B. Brf.Tox. 1980. Evolution de la gonadotropine plasmatique $t \cdot \mathrm{GtH}$ après ovulation chez la truite arc-en-ciel (Salmo gairdneri R.) et influence de la rétention des ovules. Comples Rendus Hebdomadaires des Séances de l'Académie des Sciences, Série D. Sciences Naturelles 290:799-801

JALABERT, B., ANd A. Fostif.r. 1984. The modulatory effect in vitro of oestradiol-17 $\beta$, testosterone

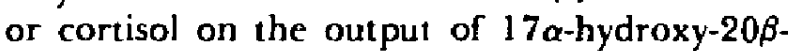
dihydroprogesterone by rainbow trout ( $\mathrm{Salmo}$ gairdneri) ovarian follicles stimulated by the maturational gonadotropin S-GTH. Reproduction, Nutrition, Développement 24:127-136.

Jiaxiu, P., W. Yust, S. RFNChEN, Y. GuXing, P. XuAN, AND X. WEIGer. 1980. On the mode of pituitary gonadotropin releasing in carps. Journal of Fisheries of China 4:121-127.

Johnes, T. M., F. W. H. Beamish, and J. C. George. 1980. Diurnal variation in the effect of exogenous indoleamines on blood metabolite levels in the rainbow trout. Comparative Biochemistry and Physiology C, Comparative Pharmacology 65: 105-109.

Kuo, C. M., ANo W. O. Watanabe. 1978. Circadian responses of teleostean oocytes to gonadotropins and prostaglandins determined by cyclic AMP concentration. Annales de Biologie Animale, Biochimie, Biophysique 18:949-956.

Lamba, V. J., S. V. Goswami, año B. I. Sundararaj: 1983. Circannual and circadian variations in plasma levels of sterojds (cortisol, estradiol $17 \beta$, estrone and testosterone) correlated with the annual gonadal cycle in the catfish, Heteropneustes fossilis (Bloch). General and Comparative Endocrinoiogy 50:205-225.

LAMBF.RT, J. G. D., G. I. C. G. M. BOSMAN, R. VAN DEN HURK, AND P. G. W. J. VAX OORIT 1978 Annual cycle of plasma oestradiol-17 $\beta$ in the female trout (Salmo gairdneri). Annales de: Biologie Animale, Biochimie, Biophysique 18:923-927.

LFATHR1,AND, J, F, ANDB. A. M(Ktow, 1973. Circadian rhythm in the plasma levels of prolactin in goldfish, Carassius auratu\& L. Journal of Interdisciplinary Cycle Research 4:137-143

Lf: BrAs, Y. M. 1979. Circadian rhuthm in brain catecholamine concentrations in the teleost: $A n$. guillo anguilla $\mathrm{L}$. Comparative Biochemistry and Physiology: C, Comparative Pharmacology 62: $115-117$.

LixCOLX, G. A., O. F. X. ALMFIUA, H. KI.ANDOF, ANI R. A. CuNingham. 1982. Hourly fluctuations in the blood levels of melatonin, prolactin, luteinizing hormone, follicle stimulating hormone, testosterone, tri-iodothyronine, thrroxine and cortisol in rams under artificial photoperiods, and 
the effecis of cranial sympathectomy. Journal of Endocrinology 92:237-250.

MACGREGor, R. In press. Seasonal and diel fluctuations of gonadal steroids in teleost fish, $n$ B. Loft, - editor. Proceedings of the 9th International Symposium on Comparative Endocrinology, Hong Kong.

Plisetskaya, E., N. Y. S. Woo, ani' J. C. Murat. 1983. Thyroid hormones in cyriostomes and fish and their role in regulation of iluermediary metabolism. Comparative Biochemistry and Physiology A, Comparative Physiology 74:179-187.

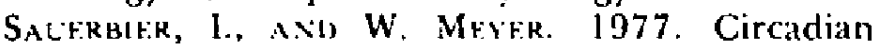
rhythms in catecholamine concentrations in organs of the common goldfish (Cnrassius auratus L.). Comparative Biochemistry and Physiolngy $\mathrm{C}$, Comparative Pharmacology 57:117-120.

Schreck, C. B., R. T'. LaCkey, and M. L. Hopwoov. 1972. Evaluation of diel variation in androgen levels of rainbow trout (Salmo gairdneri). Copeia 1972:865-868.

SCHRECK, C. B., R. T. LACKEY, AND M. L. HopwoOd. 1973. Plasma oestrogen levels in rainbow trout (Salmo gairdneri R.). Journal of Fish Biology 5: 227-230.

Scotr, A. P., ANo S. M. Barnes. 1982. Plasma levels of sex steroids in relation to ovulation and spermiation in rainbow trout (Salmo gairdneri). Pages 103-106 in C. J. J. Richter and H. J. T. Goos, compilers. Reproductive physiology of fish. PUDOC, Wageningen, Netherlands.

Scott, A. P., V. J. Bye, ANd S. M. Baynes. 1980. Seasonal variations in sex steroids of female rainbow trout (Salmo gairdneri R.). Journal of Fish Biology 17:587-592.

SCott, A. P., E. L. Sheldrick, And A. P. F. Flint. 1982. Measurement of $17 \alpha-20 \beta$-dihydroxy-4 pregnen-3-one in plasma of trout (Salmogairdneri R.) seasonal changes and response to salmon pituitary extract. General and Comparative Endocrinology 46:444-451.

Scott, A. P., ANo J. P. Sumpter. 1983. A comparison of the female reproductive cycles of autumnspawning and winter-spa wning strains of rainbow trout (Salmo gairdneri Richardson). General and Comparative Endocrinology 52:79-85.'

Spleler, R. E., ANd T. A. Norske. 1979. Diel variations in circulating levels of triiodothyronine and thyroxine in goldfish Carassius auratus. Canadian Journal of Zoology 57:665-669.

Stacry, N. E., A. F. CoOk, nNo R. E. Petrer. 1979a. Ovulatory surge of gonadotropin in the goldfish, Carassius auralus. General and Comparative Endocrinology 37:246-249.

Stacey, N. E., A. F. Cook, a.jo R. E. Pr.ter. 1979b. Spontaneous and gonadotropin induced ovulation in the goldfish, Carassius auratus L.: effects of external factors. Journal of Fish Biology 15 : 349-361.
Takashima, F., C. Wetl, R, BllaARd, L. W. CKIM, ANo A. Fosmier. In press. Acceleration of spermiation in carp by LH-RH analogue. Bulletin of the Japanese Society of Scientific Fisheries.

Van dF.R KraAk, G., H. R. LIN, E. M. Donaluson, H. M. DYE, AND G. A. HuNTER. 1983. Effects of LH-RH and of Des-Gly ${ }^{10}\left(\mathrm{D}-\mathrm{Ala}{ }^{6}\right)$ LH-RH-ethylamide on plasma gonadotropin levels and oocyte maturation in adult female coho salmon (Óncorhynchus kisu(ch). General and Comparative Endocrinology 49:470-476.

Wril, C., ANo L. W. Cris. 1983. Administration of LHRH analogues in various ways: effect on the advancement of spermiation in prespawning bandlocked salmon, Salmo salar. Aquaculture 35 : 103-115.

WuTHArad, C., N. R. BRomace, AND J. R. M. Forstr.r. 1978. Seasonal changes in reproductive function of the rainbow trout (Salmo gairdneri). Journal of Fish Biology 12:601-608.

Whitemf.AO 2 , C., N. R. Broilage, J. R. M. Forster, A.io A. J. M.ATry, 1978. The effects of alterations in photoperiod on ovarian development and spawning time in the rainbow trout (Salmo gairdneri). Annales de Biologie Animale, Biochimie, Biophysique 18:1035-1043.

WISE, P. M. 1982. Norepinephrine and dopamine activity in microdissected brain areas of the middle-aged and young rats on proestrus. Biology of Reproduction 27:562-574.

Wricht, R. S., ANd S. M. V. HUNT. 1982. A radioimmunoassay for $17 \alpha-20 \beta$ dihydroxy-4-pregnen-3-one: its use in measuring changes in serum levelsat ovulation in Atlantic salmon (Salmo salar), coho salmon (Oncorhynchus kisutch) and rainbow trout (Salmo gairdneri). General and Comparative Endocrinology 47:475-482.

Zanuy, S., and M. Carrillo. 1981. Variaciones diarias de los ácidos grasos de Sarotherodon mossambicus (Peters) expuestos a diferentes fotoperiodos. Investigacion Pesquera 45:301-308.

ZOHAR, Y, 1980. Dorsal aorta catheterization in rainbow trout. I. Its validity in the study of blood gonadotropin patterns. Reproduction, Nutrition, Développement 20:1811-1823.

Zohas, Y. 1982. L'évolution de la pulsatilité et des cycles nycthémèraux de la sécrétion gonadotrope chez la truite arc-en-ciel femelle, en relation avec le cycle sexuel annuel et par rapport à l'activité stéroïdogène de l'ovaire. Doctoral dissertation. University of Paris VI, Paris, France.

Zohar, Y., B. Breton, and A. Fostrier. 1982. Gonadotropic function during the reproduction crcle of the female rainbow trout, Salmo gairdneri, in relation to ovarian steroid secretion: in tiv'o and in ritro studies. Pages 14-18 in C. J. J. Richter and $H$. J. T. Goos, compilers. Reproductive physiology of fish. PUDOC. Wageningen, Netherlands. 